Gerontology, 1980;26:I-VI

\title{
Contents Vol. 26, 1980
}

\section{No. 1}

Experimental Section

Anthropometric Measurements in the Elderly

Vir, S.C. and Love, A.H.G

Tyrosine Aminotransferase in Senescent Rat Liver

Weber, A.; Guguen-Guillouzo, C; Szajnert, M.F.;Beck, G., and Schapira, F

Singlet Oxygen and Aging in Drosophila

Massie, H.R. and Williams, T.R 16

Effects of Long-Term Voluntary Wheel Exercise on Male and Female Wistar Rats. I. Longevity,

Body Weight, and Metabolic Rate

Goodrick, C.L 22

Clinical Section

Temporal Variation of Serum Levels of Vitamin Bn, Folate, Iron and Total Iron-Binding Capacity

Pathy, M.S. and Newcombe, R.G 34

Analysis of the List of Patients Awaiting Transfer from a Geriatric Department to Local-

Authority

Welfare Residential Accommodation and Evaluation of Priorities

Monro, J.A 43

Manual Dexterity Test in Relation to Obesity and Hyperostosis frontalis interna in Elderly

Women

Verdy, M.; Levesque, H.P.; Boghen, D.; Aube, M., and Guimond, J 50

Recent Articles in Experimental Ageing Research 53

Book Reviews 59

No. 2

Experimental Section

Age-Related Changes in Rat Muscle Collagen

Mohan, S. and Radha, E 61

Effect of Age and Short-Term Cold Stress on SDH Activity and Oxygen Consumption of Lizard Brain

Das, K. and Patnaik, B.K 68

IV Contents

Biochemical Studies on Brains of Young and Old Inbred (BC3F1) Mice

Rand, A. and Ansari, K.A 76

Brain-Life Span Conjecture: a Reevaluation of the Evidence

Economos, A.C 82

Taxonomic Differences in the Mammalian Life Span-Body Weight Relationship and the Problem of Brain Weight

Economos, A.C $\quad 90$ 
Key Enzymes of Glycolysis in Rat Brain: Effects of Single and Repetitive Treatment with

Dihydroergotoxine (Redergin $\left.{ }^{\circledR}\right)$

Djurioiõ, B.M. and Mrsulja, B.B 99

Clinical Section

Brain Blood Flow and Mean Transit Time as Related to Aging

Fujishima, M. and Omea, T 104

Critical Review

Neuroendocrine System and Aging

Everitt, A.V 108

Book Review 120

No. 3

Experimental Section

Changes in Brain Protein Synthesis during the Life Span of Male Fischer Rats

Ekstrom, R.; Liu, D.S.H., and Richardson, A 121

Influence of Growth State on Relationship between Nuclear Template Activity and in vitro

'Ageing'

Whatley, S.A. and Hill, B.T 129

Critical Review

In vitro 'Aging' and Nuclear Template Function

Whatley, S.A. and Hill, B.T 138

Clinical Section

Paget's Disease in the Head and the Neck

Simons, R.M 155

A Clinico-Pathological Survey of Thyroid Glands in Old Age

Denham, M.J. and Wills, E.J 160

Serum Elastase Levels following a Stroke in Elderly Subjects

Hall, D.A.;Middleton, R.S.W.; El-Ridi, S.S., and Zajac, A 167

Letter to the Editor 174

Book Reviews 176

Contents V

No. 4 Experimental Section

Studies on the Effects in vitro Ageing on Saturable and Nonsaturable Sugar Uptake in Cultured Human Skin Fibroblasts

Germinario, R.J.; Oliveira, M., and Taylor, M

Chronic Lathyrism and Atheromatosis in the Rat Protective Effect of Metformin

Bouissou, H.; Thiers, J.C.; Douste-Blazy, L.; Pieraggi, M.T., and Julian, M

188

Alternative States of Amoebae. Studies on Nuclear RNA and DNA Synthesis

Kaufmann, M.C. and Rao, M.V.N 200

Fine Structural Effects of Hypophysectomy on the Aging Rat Pineal Gland

Johnson, J.E., Jr 206

Age-Related Biochemical Changes in Human Descemet's Membrane

Freeman, I.L.; Vergnes, J.-P., and Brown, S.I

217

Clinical Section

Testosterone and Testosterone Precursors in the Spermatic Vein and in the Testicular Tissue of Old Men

Pirke, K.M.; Sintermann, R., and Vogt, H.-J 221 
Recent Articles in Experimental Ageing Research

Book Reviews 236

Announcement $\quad 240$

No. 5

Experimental Section

Effect of Treatment with Phenformin, Diphenylhydantoin or Z,-Dopa on Life Span and Tumour Incidence in $\mathrm{C} 3 \mathrm{H} / \mathrm{Sn}$ Mice

Dilman, V.M. and Anisimov, V.N 241

Age-Related Changes in Oxygen Consumption and the SDH Activity of Liver Homogenate of Male Garden Lizards: Effect of Malonate and Short-Term Cold Stress

Kara, T.C. and Patnaik, B.K 247

Kallikrein-Kinin System and Adenosine Metabolism System of Blood and Heart and Their

Changes at Hypothalamic-Hypophyseal Stimulation in Rabbits of Different Age

Frolkis,V.V.;Frolkis, R.A.;Pugach, B.V.;Gunina, L.M., and Rushkevich, Y.E 254

Age-Associated Changes in Deoxyglucose Uptake in Whole Brain

Le Poncin-Lafitte, M. and Rapin, J.R 265

Effects of Centrally and Systemically Administered E-Tyrosine and L-Leucine on Ovarian

Function in the Old Rat

Cooper, R.L. and Linnoila, M 270

Debate

Implications of the Reorganization of the Cell Genome for Aging or Immortalization of Dividing Cells in vitro

Macieira-Coelho, A 276

VI Contents

Clinical Section

Urate Excretion in Old Age

Stavroulaki-Tsapara, A.; Papanayiotou, P., and Dontas, A.S 283

Characteristics of Urinary Incontinence in Bedridden Geriatric Patients

Minamisawa, $\mathrm{H} \quad 290$

Book Reviews 298

No. 6

Experimental Section

Differences between Natural Ageing and Radio-Induced Shortening of the Life Expectancy in

Drosophila melanogaster

Giess, M.C 301

Morphological and Histochemical Studies in Human Rib Cartilage Chondrons of Different Age

Groups

Wobst, R.; Hommel, G., and Sames, K

Age-Dependent Changes of DNA Replication in Rat Spleen and Kidney

Levitsky, E.L 321

Clinical Section

Changes in Erythrocyte Membrane Cation Carrier with Age in Women

Naylor, G.J.; Dick, E.G.; Smith, A.H.W.; Dick, D.A.T.; McHarg, A.M., and Chambers, C.A 327

Critical Review

Cellular Immunosenescence 
Leech, S.H 330

Recent Articles in Experimental Ageing Research 346

Author Index 351

Subject Index 353 